\title{
Thermohydraulic Analysis of Shell-and-Tube Heat Exchanger with Segmental Baffles
}

\author{
Amarjit Singh $^{1}$ and Satbir S. Sehgal ${ }^{2}$ \\ ${ }^{1}$ Department of Mechanical Engineering, RPC, Railmajra 144533, India \\ ${ }^{2}$ Department of Mechanical Engineering, Chandigarh University, Gharuan 140413, India \\ Correspondence should be addressed to Amarjit Singh; sandhar88@gmail.com
}

Received 30 June 2013; Accepted 1 August 2013

Academic Editors: C. Chen, I. Poulios, and A. M. Seayad

Copyright (c) 2013 A. Singh and S. S. Sehgal. This is an open access article distributed under the Creative Commons Attribution License, which permits unrestricted use, distribution, and reproduction in any medium, provided the original work is properly cited.

In this study, the experimental analysis was performed on the shell-and-tube type heat exchanger containing segmental baffles at different orientations. In the current work, three angular orientations $(\theta) 0^{\circ}, 30^{\circ}$, and $60^{\circ}$ of the baffles were analyzed for laminar flow having the Reynolds number range 303-1516. It was observed that, with increase of Reynolds number from 303 to 1516, there was a $94.8 \%$ increase in Nusselt number and $282.9 \%$ increase in pressure drop. Due to increase of Reynolds number from 303 to 1516 , there is a decrease in nondimensional temperature factor for cold water $(\omega)$ by $57.7 \%$ and hot water $(\xi)$ by $57.1 \%$, respectively.

\section{Introduction}

A heat exchanger is a device built for efficient heat transfer from one medium to another in order to carry and process energy [1]. It is widely used in petroleum refineries, chemical plants, petrochemical plants, natural gas processing, air conditioning, refrigeration, and automotive applications. The most commonly used type of heat exchanger is the shelland-tube heat exchanger. To increase the heat transfer rate in shell and tube type heat exchanger, the segmental baffles are introduced inside the cover pipe [2-6]. The flow arrangement used in analysis is laminar counter flow as it is more efficient than parallel flow arrangement [7]. The different orientations of baffles in heat exchanger [8-10] are given in Figure 1.

The common focus of publication is to predict the variation of LMTD, heat transfer coefficient, Nusselt number, and pressure drop with change in values of Reynolds number for $0^{\circ}, 30^{\circ}$, and $60^{\circ}$ baffles situated in heat exchanger as shown in Figure 1. The Reynolds number will be varying from 303 to 1516.

The enhancement of Nusselt number with increase in Reynolds number will be presented by Zohir [11], Tandiroglu [12], and Promvonge [13]. The heat transfer coefficient values are calculated using the log-mean-temperature-difference (LMTD) method [14] from the temperature difference and the heat transfer area. Gay et al. [15] and Mehrabian et al. [16] concluded that the heat transfer coefficient increases with inserting baffles. Thundil et al. [17] observed that the pressure drop will decrease with increasing baffle inclination angle and the heat transfer rate increases with increasing baffle inclination angle.

\section{Test Specimen}

A variety of different strategies are available to improve the performance of shell-and-tube type heat exchanger as discussed by Walde [18]. The present paper mainly attempts to study the different effects in shell-and-tube heat exchanger by increasing Reynolds number with segmental baffles at $0^{\circ}, 30^{\circ}$, and $60^{\circ}$ situated in the cover pipe. The model is situated with four segmental baffles. The various dimensions used in heat exchanger are shown in Figure 2. The working fluid used is deionized water. The material used for the design of model is galvanized iron. The geometric parameters of shell-and-tube heat exchanger are given in Table 1. 


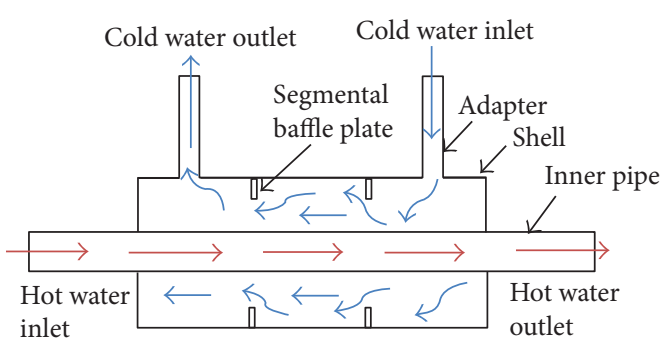

(a)

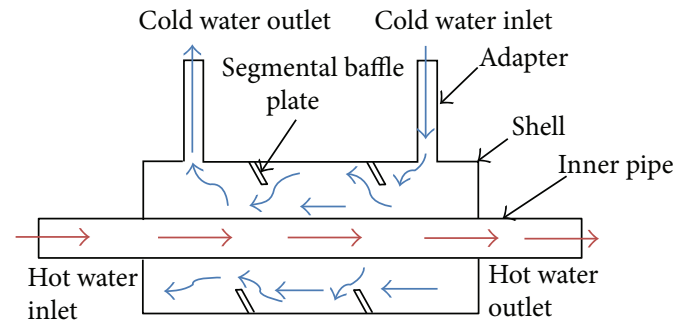

(b)

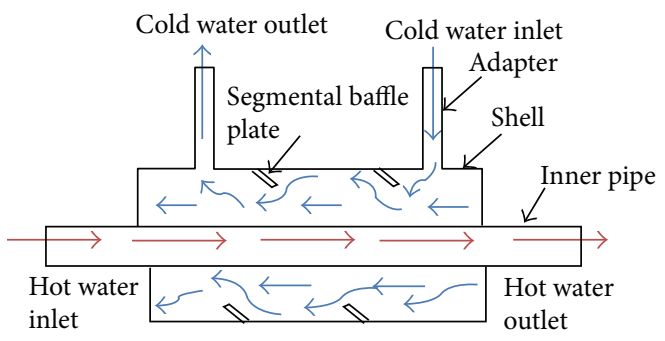

(c)

FIGURE 1: Shell-and-tube type heat exchanger having (a) $0^{\circ}$, (b) $30^{\circ}$, and (c) $60^{\circ}$ baffle angles.

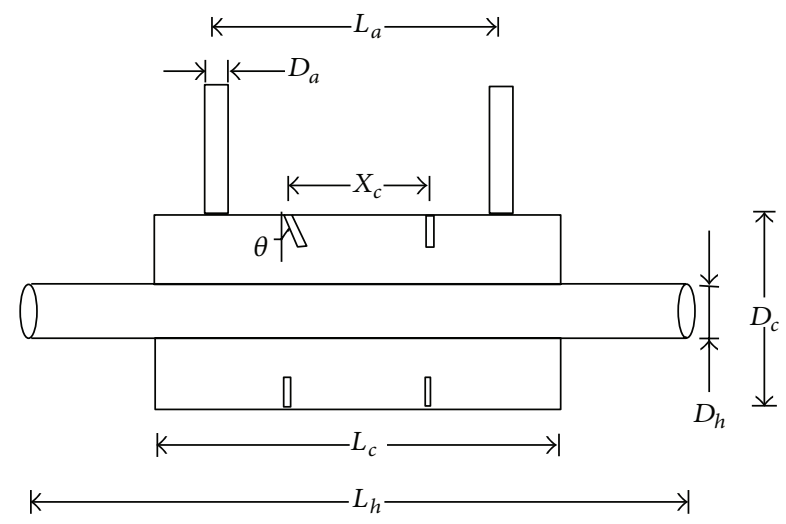

FIGURE 2: Dimensions used in heat exchanger.

\section{Results and Discussion}

In the present study, different cases were studied to understand the LMTD values, Nusselt number, heat transfer coefficient, and pressure drop of shell-and-tube type heat exchanger having hot water and cold water inlets. Performance comparison and other details are given in Table 2.

The variation of LMTD values with different Reynolds numbers is shown in Figure 3. The variation of heat transfer coefficient with Reynolds number at different inlet temperatures is shown in Figure 4, and the variation of Nusselt number with Reynolds number is shown in Figure 5. Figure 6 shows the variation of ratio of temperature difference $(\omega)$ for cold water with increasing Reynolds number, and the variation of ratio of temperature difference $(\xi)$ for hot water with increasing Reynolds number is shown in Figure 7.

Figure 3 shows the variation of LMTD with Reynolds number. It was observed that, with the increase of Reynolds
TABLE 1: Main dimensions and features in heat exchanger.

\begin{tabular}{lll}
\hline$\alpha$ & $L_{a} / D_{c}$ & 1.86 \\
$\beta$ & $L_{c} / D_{c}$ & 2.67 \\
$\gamma$ & $L_{h} / D_{h}$ & 16.6 \\
$\delta$ & $L_{c} / X_{c}$ & 2.86 \\
\hline$\theta: 0^{\circ}, 30^{\circ}$, and $60^{\circ}$. & &
\end{tabular}

TABLE 2: Data reduction.

\begin{tabular}{|c|c|c|}
\hline $\begin{array}{l}\text { S. } \\
\text { no. }\end{array}$ & Parameters & Data reduction \\
\hline 1. & $\begin{array}{l}\text { Heat transfer } \\
\text { coefficient }\end{array}$ & $h=\frac{m \cdot C \cdot \Delta t}{\pi \cdot D \cdot L \cdot \Delta t_{m}}$ \\
\hline 2. & $\begin{array}{l}\text { Logarithmic } \\
\text { mean } \\
\text { temperature } \\
\text { difference }\end{array}$ & $\Delta T_{m}=\frac{\left(T_{h(\mathrm{in})}-T_{c(\mathrm{in})}\right)-\left(T_{h(\mathrm{out})}-T_{c(\mathrm{out})}\right)}{\ln \left(\left(T_{h(\mathrm{in})}-T_{c(\mathrm{in})}\right) /\left(T_{h(\mathrm{out})}-T_{c(\mathrm{out})}\right)\right)}$ \\
\hline 3. & $\begin{array}{l}\text { Nondimensional } \\
\text { temperature } \\
\text { factor for cold } \\
\text { water }\end{array}$ & $\omega=\frac{t_{c(\text { out })}-t_{c(\text { in })}}{t_{c(\text { out })}}$ \\
\hline 4. & $\begin{array}{l}\text { Nondimensional } \\
\text { temperature } \\
\text { factor for hot } \\
\text { water }\end{array}$ & $\xi=\frac{t_{h(\mathrm{in})}-t_{h(\mathrm{out})}}{t_{h(\mathrm{in})}}$ \\
\hline 5. & Nusselt number & $\mathrm{Nu}=\frac{h L}{K}$ \\
\hline 6. & $\begin{array}{l}\text { Reynolds } \\
\text { number }\end{array}$ & $\operatorname{Re}=\frac{\rho V D}{\mu}$ \\
\hline
\end{tabular}

number from 303 to 1516 there was 23.15 to $38.5 \%$ increase in LMTD values. The increase in LMTD value with Reynolds 


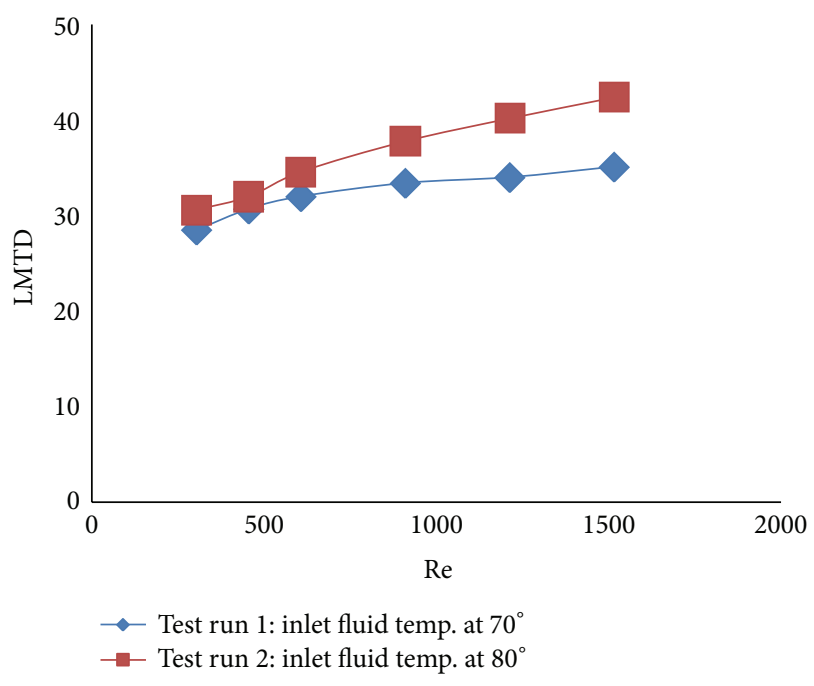

FIgURE 3: Variation of LMTD with Reynolds number.

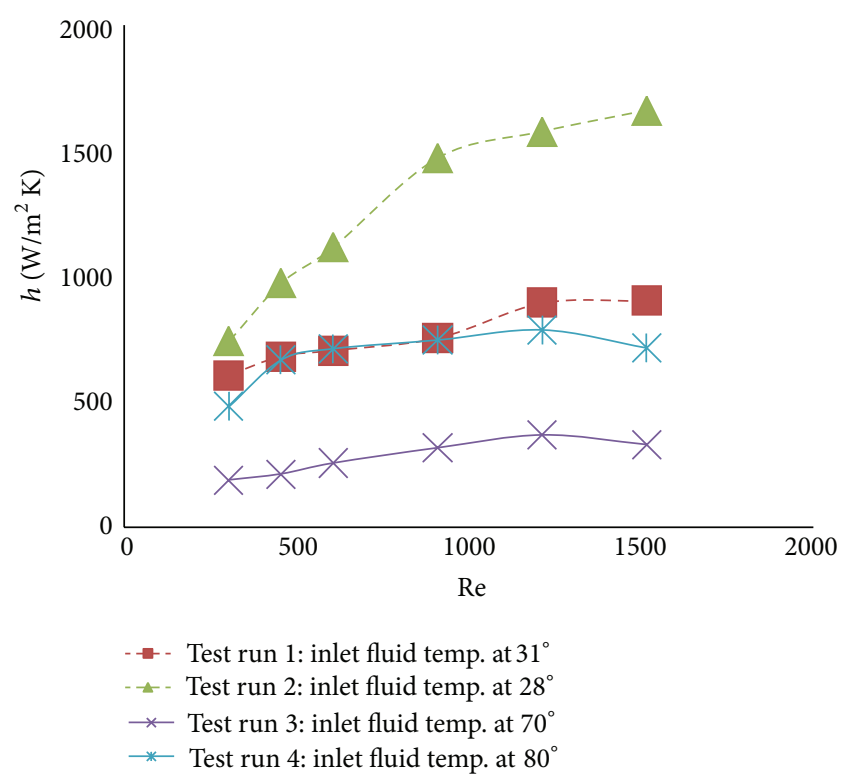

FIGURE 4: Variation of heat transfer coefficient versus Reynolds number for different inlet fluid temperatures.

number may be attributed to less retention time within the heat exchanger for the same length of flow.

Figure 4 shows the variation of the heat transfer coefficient with Reynolds number. With increase of Reynolds number from 303 to 1516, the increase of heat transfer coefficient was $95.1 \%$. The increase of heat transfer coefficient is attributed to the increase of mass flow rate due to which the heat transfer rate increases.

Figure 5 shows the variation of Nusselt number with Reynolds number. It was observed, that with the increase of Reynolds number from 303 to 1516, there was a $94.8 \%$ increase in Nusselt number. The increase in Nusselt number is attributed to the enhancement in heat transfer rate with increase in velocity of fluid.

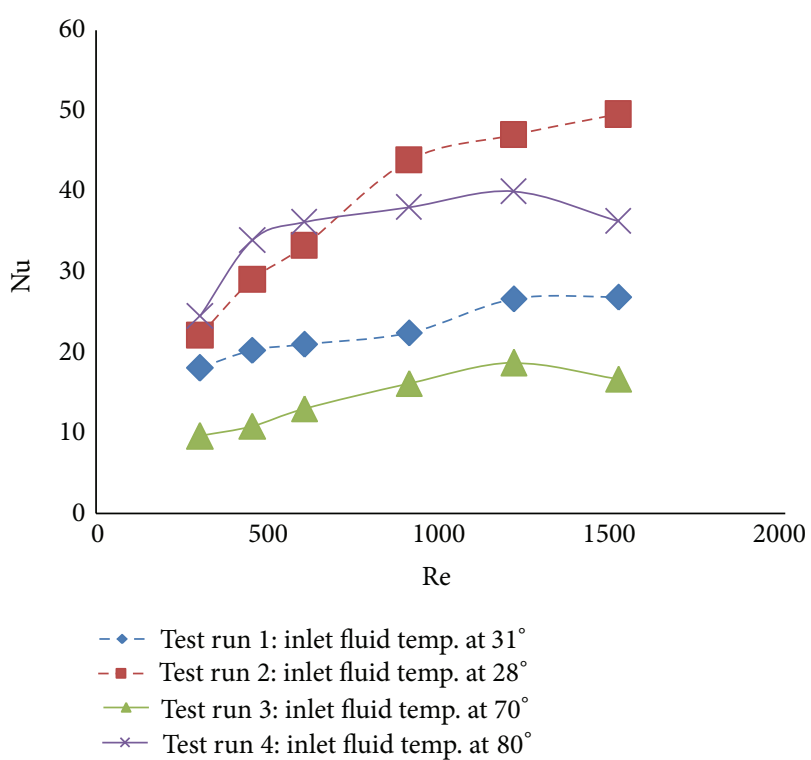

FIGURE 5: Variation of Nusselt number with Reynolds number for different inlet fluid temperatures.

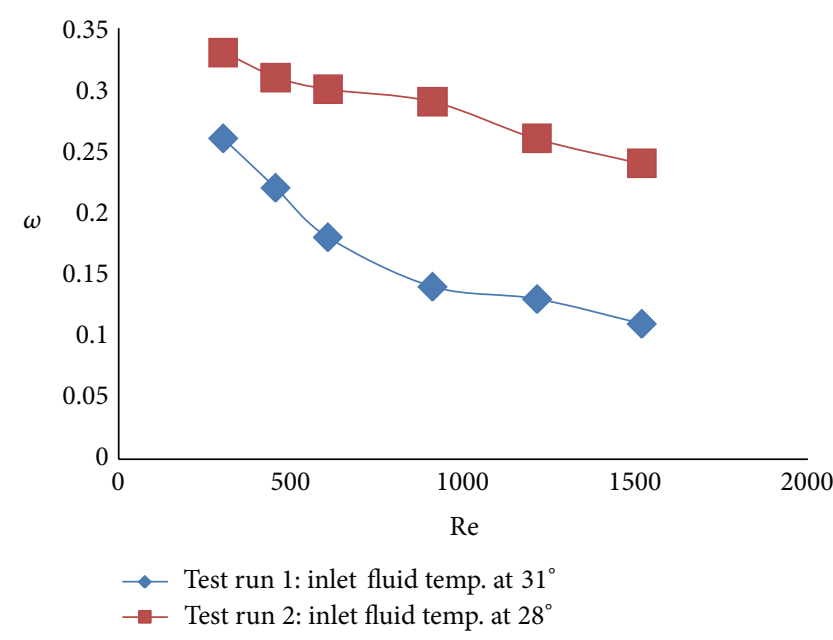

FIgURE 6: Variation of $\omega$ with Reynolds number (for cold water inlet).

Figure 8 shows the change of pressure drop with variation in Reynolds number. It was observed that the pressure drop increases with the increase in Reynolds number up to $282.9 \%$. The measured pressure drop is in good agreement with the estimated value. A gradual change in the pressure drop with Reynolds number is attributed to the temperature dependence of fluid viscosity and the increasing contraction and expansion pressure losses at the inlet and outlet portion of the heat exchanger, respectively.

Figure 9 shows the variation of the heat transfer coefficient with Reynolds number for three different baffle orientations. It was observed that, with the introduction of the baffles, the heat transfer coefficient increases leading to more heat transfer rate due to introduction of swirl and more convective surface area. It was also observed that, as the angle 


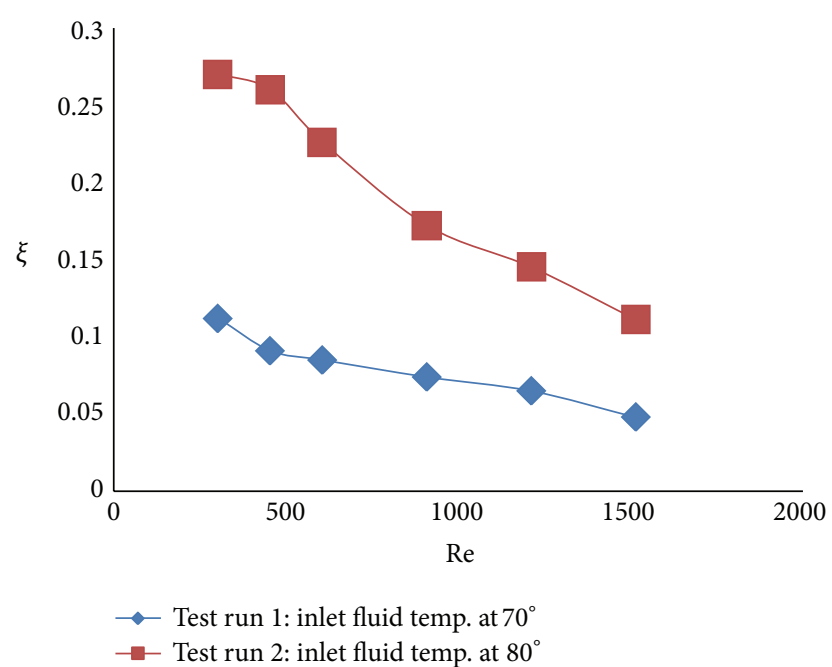

FIGURE 7: Variation of $\xi$ with Reynolds number (for hot water inlet).

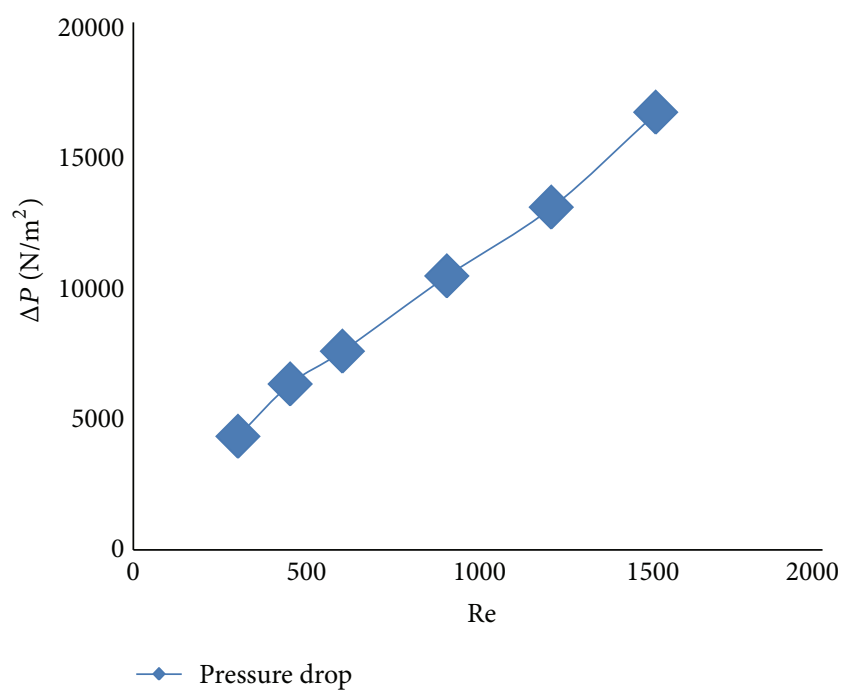

FIGURE 8: Variation of total pressure drop versus Reynolds number for $0^{\circ}$ baffle orientations.

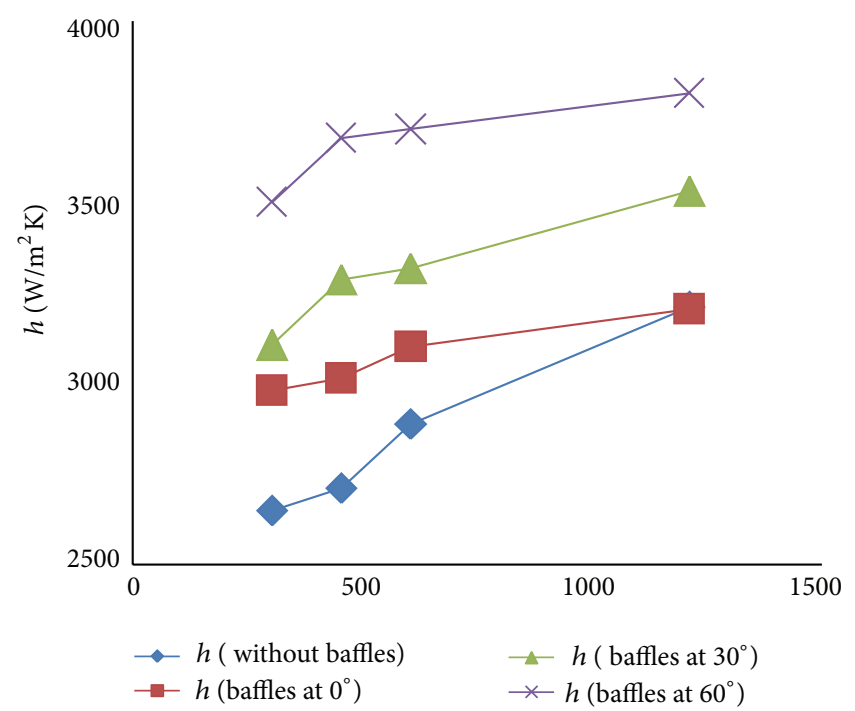

FIgURE 9: Variation of heat transfer coefficient versus Reynolds number for different baffle orientation. of inclination increases from $0^{\circ}$ to $60^{\circ}$, the heat transfer coefficient value increases due to increase in swirl.

\section{Conclusion}

In this paper, experimental study of shell-and-tube heat exchanger is conducted to calculate the heat transfer coefficient, LMTD, Nusselt number, and pressure drop at different Reynolds numbers (303-1516). It is concluded that the increase in Reynolds number has a significant impact on different parameters of shell-and-tube type heat exchanger. The major findings are summarized as follows.

(i) The heat transfer coefficient increases with increase in Reynolds number in shell-and-tube heat exchanger for both hot fluid inlet and cold fluid inlet.

(ii) The Nusselt number increases with increase in Reynolds number in shell-and-tube heat exchanger for both hot fluid inlet and cold fluid inlet.

(iii) The value of LMTD increases with increase in Reynolds number from 303 to 1516.

(iv) The value of temperature constants $\xi$ and $\omega$ decreased with increase in Reynolds number.

(v) The value of pressure drop gradually increases with increase in Reynolds number.

\section{Nomenclature}

$C: \quad$ Specific heat of water $(\mathrm{J} / \mathrm{kg} \mathrm{K})$

$D_{a}:$ Diameter of adapter $(\mathrm{m})$

$D_{c}$ : Diameter of cover pipe (m)

$D_{h}$ : Diameter of inner pipe $(\mathrm{m})$

$h$ : Heat transfer coefficient $\left(\mathrm{W} / \mathrm{m}^{2} \mathrm{~K}\right)$

$K: \quad$ Thermal conductivity of water $(\mathrm{W} / \mathrm{m} \mathrm{K})$

$L_{a}$ : Centre distance between two adapters

$L_{c}: \quad$ Length of cover pipe (m)

$L_{h}$ : Length of inner pipe (m)

$m$ : Mass flow rate $(\mathrm{kg} / \mathrm{s})$

Re: Reynolds number

$V: \quad$ Velocity of water $(\mathrm{m} / \mathrm{s})$

$X_{c}$ : Centre distance between two baffles

$\rho: \quad$ Density of water $\left(\mathrm{kg} / \mathrm{m}^{3}\right)$

$\mu: \quad$ Viscosity of water $\left(\mathrm{N} \mathrm{s} / \mathrm{m}^{2}\right)$

$\Delta P: \quad$ Pressure drop $\left(\mathrm{N} / \mathrm{m}^{2}\right)$

$\Delta T: \quad$ Change in temperature $\left({ }^{\circ} \mathrm{C}\right)$

$\Delta T_{m}$ : Logarithmic mean temperature difference

$\theta: \quad$ Inclination angle

$\alpha$ : $\quad$ Ratio of adapter pitch to cover pipe internal diameter

$\beta$ : $\quad$ Ratio of length to internal diameter of cover pipe

$\gamma$ : $\quad$ Ratio of length to internal diameter of inner pipe

$\delta$ : $\quad$ Ratio of length of cover pipe to baffle pitch. 


\section{Subscripts}

$\begin{array}{ll}a: & \text { Adapter } \\ c: & \text { Cold water } \\ h: & \text { Hot water } \\ \text { in: Water inlet } \\ \text { out: }\end{array}$

\section{References}

[1] B. T. L. Alawa and V. Egwanwo, "Numerical analysis of heat transfer in heat exchangers," International Journal of Applied Science and Technology, vol. 2, no. 4, pp. 60-64, 2012.

[2] C. Berner, F. Durst, and D. M. McEligot, "Flow around baffles," Journal of Heat Transfer, vol. 106, no. 4, pp. 743-749, 1984.

[3] E. S. Gaddis and V. Gnielinski, "Pressure drop on the shell side of shell-and-tube heat exchangers with segmental baffles," Chemical Engineering and Processing, vol. 36, no. 2, pp. 149-159, 1997.

[4] M. A. Habib, A. M. Mobarak, M. A. Sallak, E. A. A. Hadi, and R. I. Affify, "Experimental investigation of heat transfer and flow over baffles of different heights," Journal of Heat Transfer, vol. 116, no. 2, pp. 363-368, 1994.

[5] S. T. Gajusingh, N. Shaikh, and K. Siddiqui, "Influence of a rectangular baffle on the downstream flow structure," Experimental Thermal and Fluid Science, vol. 34, no. 5, pp. 590-602, 2010.

[6] V. K. Chalwa and N. Kadli, "Study of variation for pressure drop and temperature distribution in a shell and tube heat exchanger in case of vertical baffle," Mechanica Confab, vol. 2, no. 1, pp. $17-25,2013$.

[7] L. Z. Zhang, "Heat and mass transfer in a quasi-counter flow membrane-based total heat exchanger," International Journal of Heat and Mass Transfer, vol. 53, no. 23-24, pp. 5478-5486, 2010.

[8] A. Singh, H. Singh, S. K. Gandhi, and S. Sehgal, "Computational analysis of the effect of segmental baffle orientation in shell and tube heat exchanger," International Journal of Mechanical Science and Civil Engineering, vol. 2, no. 2, pp. 10-14, 2013.

[9] K. Mohammadi, W. Heidemann, and H. Müller-Steinhagen, "Numerical investigation of the effect of baffle orientation on heat transfer and pressure drop in a shell and tube heat exchanger with leakage flows," Heat Transfer Engineering, vol. 30, no. 14, pp. 1123-1135, 2009.

[10] Nasiruddin and M. H. K. Siddiqui, "Heat transfer augmentation in a heat exchanger tube using a baffle," International Journal of Heat and Fluid Flow, vol. 28, no. 2, pp. 318-328, 2007.

[11] A. E. Zohir, "Heat transfer characteristics in a heat exchanger for turbulent pulsating water flow with different amplitudes," Journal of American Science, vol. 8, no. 2, pp. 241-250, 2012.

[12] A. Tandiroglu, "Effect of flow geometry parameters on transient heat transfer for turbulent flow in a circular tube with baffle inserts," International Journal of Heat and Mass Transfer, vol. 49, no. 9-10, pp. 1559-1567, 2006.

[13] P. Promvonge, "Heat transfer and pressure drop in a channel with multiple $6^{\circ}$ V-baffles," International Communications in Heat and Mass Transfer, vol. 37, no. 7, pp. 835-840, 2010.

[14] F. P. Incropera and D. P. Dewitt, Introduction to Heat Transferedition, John Wiley \& Sons, New York, NY, USA, 6th edition, 2006.

[15] B. Gay, N. V. Mackley, and J. D. Jenkins, "Shell-side heat transfer in baffled cylindrical shell- and tube exchangers-an electrochemical mass-transfer modelling technique," International
Journal of Heat and Mass Transfer, vol. 19, no. 9, pp. 995-1002, 1976.

[16] M. A. Mehrabian, S. H. Mansouri, and G. A. Sheikhzadeh, "The overall heat transfer characteristics of double pipe heat exchanger: comparison of experimental data with predictions of standard correlations," International Journal of Engineering, vol. 15, no. 4, pp. 395-406, 2012.

[17] R. Thundil, K. Raj, and S. Ganne, "Shell side numerical analysis of a shell and tube heat exchanger considering the effects of baffle inclination angle on fluid flow," International Journal of Thermal Science, vol. 16, no. 4, pp. 1165-1174, 2012.

[18] S. P. Walde, "Review of heat transfer enhancement in different types of baffles and their orientations," International Journal of Engineering Science and Technology, vol. 4, no. 4, pp. 1367-1372, 2012. 

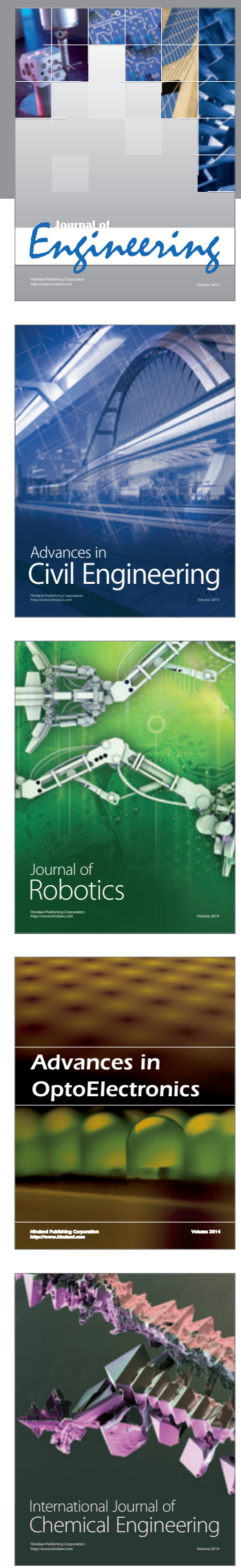

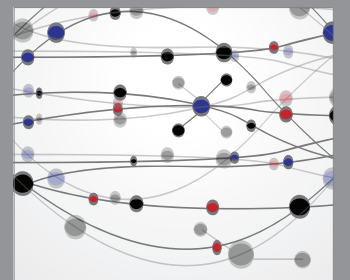

The Scientific World Journal
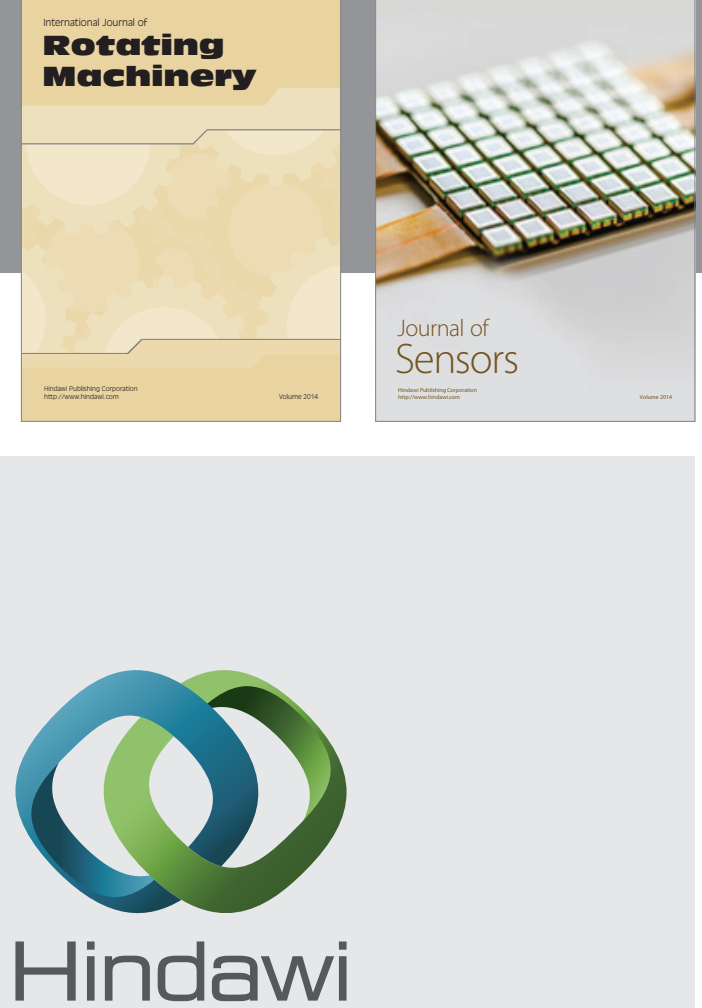

Submit your manuscripts at http://www.hindawi.com
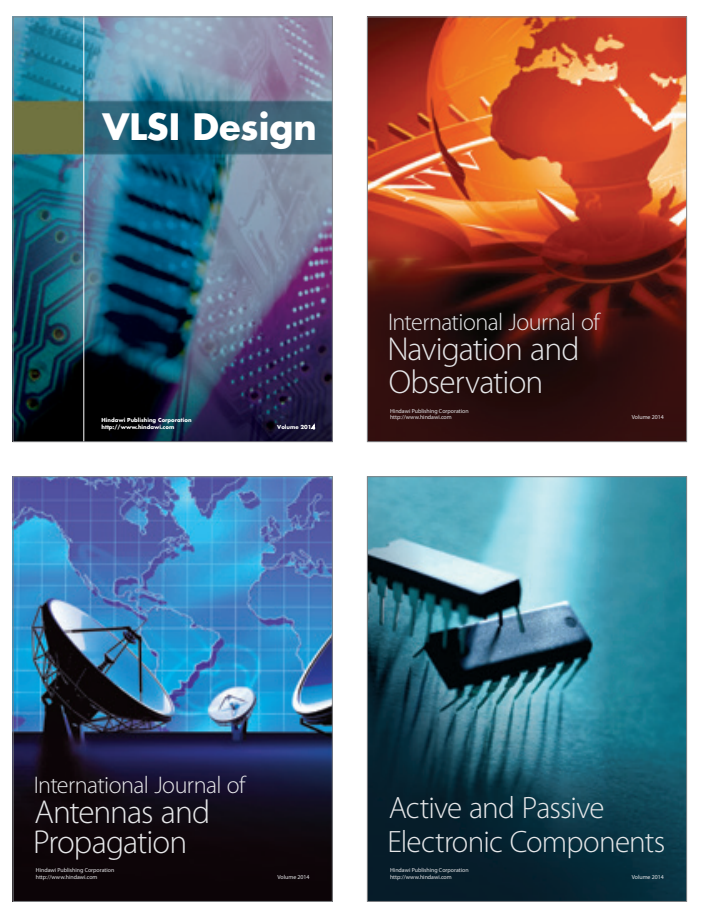
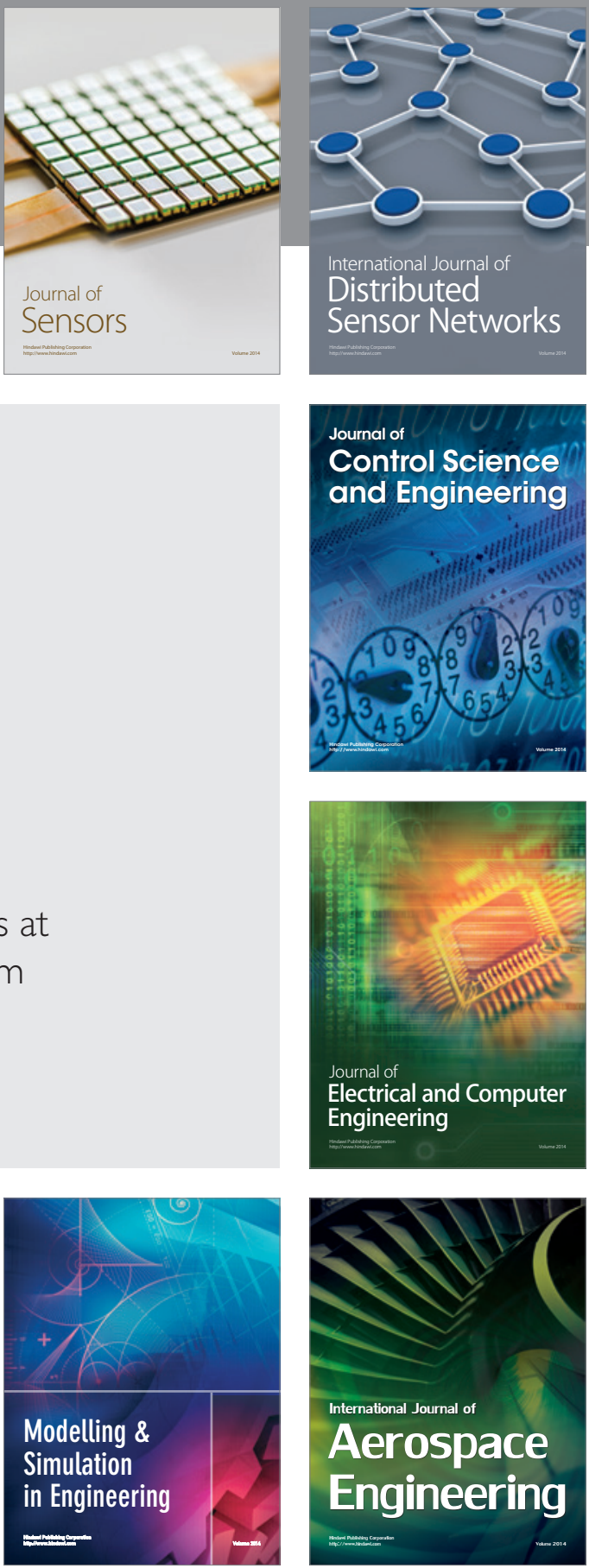

Journal of

Control Science

and Engineering
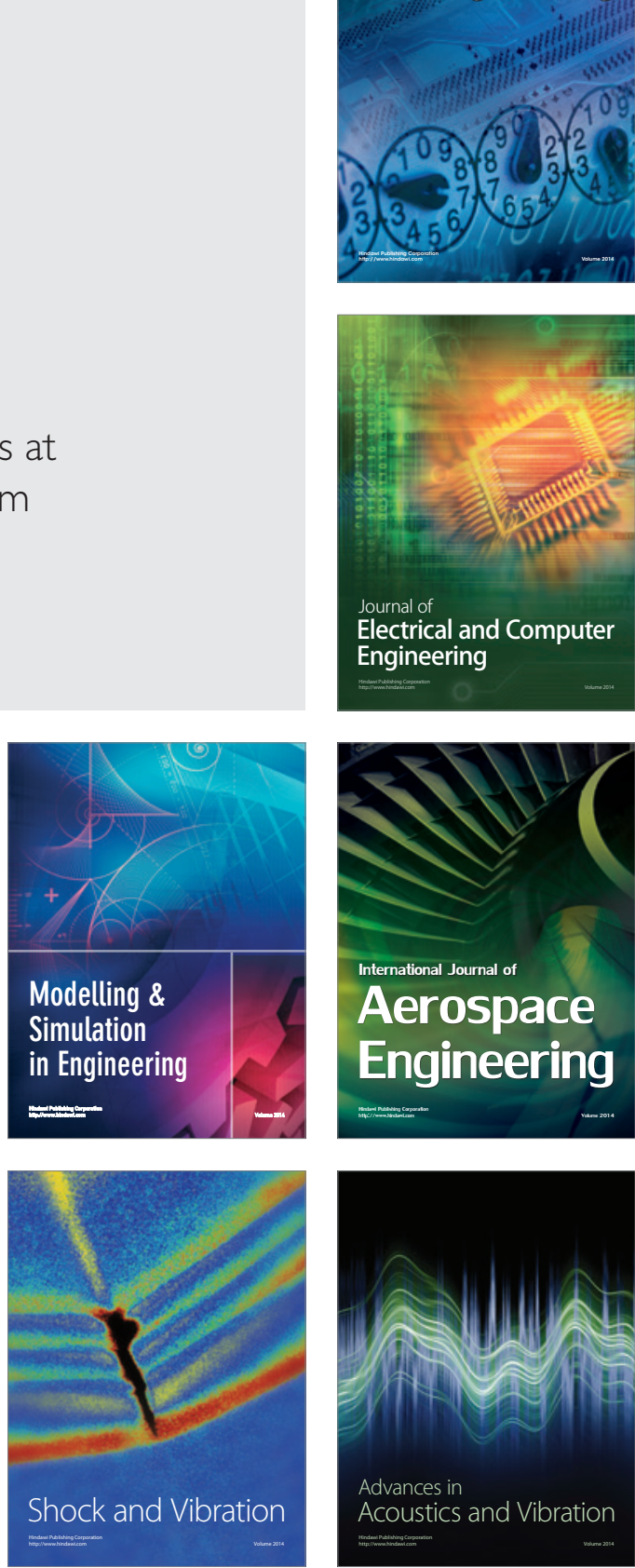